\title{
Article \\ Can Financial Literacy Explain Lack of Investment in Risky Assets in Japan?
}

\author{
Mostafa Saidur Rahim Khan ${ }^{1, *(\mathbb{D})}$, Naheed Rabbani ${ }^{2}$ and Yoshihiko Kadoya ${ }^{1}$ (D) \\ 1 School of Economics, Hiroshima University, 1-2-1 Kagamiyama, Hiroshima 739-8525, Japan; \\ ykadoya@hiroshima-u.ac.jp \\ 2 Department of Banking and Insurance, University of Dhaka, Dhaka 1000, Bangladesh; naheed.bin@du.ac.bd \\ * Correspondence: khan@hiroshima-u.ac.jp
}

check for updates

Citation: Khan, M.S.R.; Rabbani, N.; Kadoya, Y. Can Financial Literacy Explain Lack of Investment in Risky Assets in Japan? Sustainability 2021, 13, 12616. https://doi.org/10.3390/ su132212616

Academic Editor: Klaus Reiner Schenk-Hoppé

Received: 14 October 2021

Accepted: 12 November 2021

Published: 15 November 2021

Publisher's Note: MDPI stays neutral with regard to jurisdictional claims in published maps and institutional affiliations.

Copyright: (c) 2021 by the authors. Licensee MDPI, Basel, Switzerland. This article is an open access article distributed under the terms and conditions of the Creative Commons Attribution (CC BY) license (https:// creativecommons.org/licenses/by/ $4.0 /)$.

\begin{abstract}
Although household savings in Japan are among the highest in the world, investment in risky assets is still very low. This study examines whether financial literacy explains the lack of investment in risky assets in Japan. We use data from the Preference Parameter Study, a nationwide survey in Japan that has been conducted by Osaka University. We use investment in stocks, investment trusts, futures/options, Japanese government bonds, government bonds of foreign countries, and foreign currency deposits as a proxy for investment in risky assets. Our results show that investment in risky assets is higher among financially literate people. Moreover, financial literacy has a significantly positive association with investment in risky assets even after controlling the demographic, socio-economic, and psychological factors. We check the robustness of the association between financial literacy and investment in risky assets by segregating investment in risky assets into investment in equity securities and investment in bonds and foreign currencies. Financial literacy is found to be associated with both investment in equity securities and investment in bonds and foreign currencies. Our results are also robust in terms of the endogeneity issue. The results imply that investment in risky assets in financial markets could be increased by introducing financial literacy programs at a mass level.
\end{abstract}

Keywords: financial literacy; risky assets; equity securities; debt securities; household investment; financial market; Japan

\section{Introduction}

The lack of investment in risky assets has been a long-standing puzzle in empirical finance. Risky assets are generally associated with price volatility, but also offer higher returns to investors. Risky assets comprise a significant portion of assets traded in the financial markets. Irrespective of the high capacity to generate returns, investment in risky assets across the world is quite low. Empirical evidence indicates that more than 50 percent of U.S. households do not invest in stocks, while the participation of European households in the stock market is even lower [1-3]. The challenge of directing people's savings in the financial market is particularly confusing in Japan because it is traditionally found that people hold cash and place it in deposits, which generate little to no income. Iwamoto et al. [4] reported that Japanese households held $¥ 844$ trillion in cash at home and in low-interest savings accounts. Despite having one of the highest levels of household savings in the world, the lack of investment in financial market instruments by Japanese households has been evident in empirical studies. Empirical evidence shows that 29 percent of Japanese households participated in the stock market in 1998 [5]; however, the Bank of Japan reported that, approximately ten years later, only 6 percent of Japanese household held stocks compared to 33 percent in the U.S. and 15 percent in Europe [4]. Although long-standing economic sluggishness has kept the stock market at bay, studies have shown that returns from stocks are still the highest among the available investment opportunities in Japan [6]. Even the poorly performing government bonds, due to ultra-easy monetary 
policy, have started to upend as global debt rally squeezes returns [7]. Japanese government bonds have appeared as one of the highest yielding government bonds in the world and are a viable alternative to take a long position [7]. Thus, it is important to study why people do not invest their savings in financial markets when returns from risky assets are higher than holding cash. The issue is also important due to the changing nature of demography in Japan. As the gap between retirement age and average life expectancy has been increasing over the last several decades, people must now consider stable income for some decades after retirement. Holding cash, which most older Japanese people like to do, is not going to increase their financial security as the value of money erodes over time due to inflation. Learning from previous studies suggests that investment in financial market instruments is the best solution because they offer the highest long-term investment returns.

During the last two decades, financial literacy has been studied as a means to improve people's ability to make better economic and financial decisions. Previous studies argued that financial literacy helps to improve people's savings, accumulate wealth, plan for retirement, and so on. Financial literacy, for obvious reasons, has also been found to affect peoples' investment behavior. Van Rooij et al. [8] was the first to explain the stock market participation puzzle in terms of financial literacy. Using a sample from the Netherlands, they argued that financially literate people are more likely to invest in stocks to generate higher long-term returns. Later, Khan et al. [9] and Yoong [10] examined the relationship in the U.S., and Thomas and Spataro [11] considered several European countries and provided evidence that confirmed that financial literacy could explain people's lack of investment in stocks. Yoong [10] and Thomas and Spataro [11] found that financially literate people were more likely to invest in stocks. Khan et al. [9] found that financially literate people were more likely to invest both in stocks and bonds and foreign currencies. As Khan et al. [9] investigated the association between financial literacy and investment in risky assets in the United States using the same methodology and source of data as we did in this study, the findings of both studies could be compared to observe the role of financial literacy in investment in risky assets in two culturally different countries. Moreover, two recent studies have provided conflicting results, making the implication of financial literacy on stock investment inconclusive in Japan. Yamori and Ueyama [12] found that financially literate people were more likely to invest in stocks. On the other hand, Kawamura et al. [13] found that financially literate people tended to take too many risks by investing in financial and cryptocurrency markets for speculative purposes, over-borrowing, and maintaining a naïve financial attitude. Consequently, the association between financial literacy and stock investment requires further study in Japan.

As there has been no study on the role of financial literacy in explaining investment in risky assets in Japan and previous studies have provided conflicting evidence regarding the role of financial literacy in investment in stocks, this study examines the association between financial literacy and investment in risky assets in Japan. Our study is related to the one by Yamori and Ueyama [12] but has important differences as well. Yamori and Ueyama [12] investigated how financial literacy is associated with investment in equity securities; however, we extend the scope by incorporating other risky assets, such as Japanese government bonds, government bonds of foreign countries, and foreign currency deposits. Understanding how financial literacy is related to investment in bonds and foreign currency deposits, in addition to equities, is important because the bond and currency markets comprise a significant portion of the overall financial market in Japan. We hypothesize that financially literate people are more likely to invest in risky assets. We argue that financially literate people are knowledgeable about the risk to return trade off, face less participation entry barriers in the financial market, and have less information asymmetry, making them more eligible and confident to invest in risky assets. The findings of previous studies on the association between financial literacy and savings, wealth accumulation, retirement planning, and anxiety about post-retirement life in Japan are consistent with our hypothesis [14-16]. Our study makes at least two significant contributions to the existing literature. First, to the best of our knowledge, this is the first study in Japan that examines 
how financial literacy is related to investment in bonds and foreign currencies in addition to equity securities. Second, our study includes the psychological characteristics of investors in terms of the association between financial literacy and investment in risky assets.

The remainder of this paper is organized as follows: Section 2 describes the variables, Section 3 shows the data and methods, Section 4 presents the empirical findings, Section 5 discusses the results, and Section 6 concludes the paper.

\section{Definition and Measurement of Variables}

To examine whether financial literacy explains the lack of investment in risky assets, we controlled several factors that have been found to affect investment in risky assets. The definition and measurement of variables is discussed below.

\subsection{Dependent Variable}

The dependent variable, investment in risky assets, is measured as respondents' holdings of risky assets as a percentage of total assets. Investment in risky assets is also measured in terms of percentage of respondents holding those assets. Risky assets include investment in stocks, investment trusts, and futures/options, Japanese government bonds, government bonds of foreign countries, and foreign currency deposits. The reason for considering these assets risky is that their value is subject to changes in market conditions, currency rates, and interest rates.

\subsection{Independent and Control Variables}

The independent variable of our study is financial literacy, measured by respondents ability to understand basic financial calculations, inflation, and risks of financial securities. The measurement of financial literacy is important because previous studies have used different measures for it. Lusardi and Mitchell $[17,18]$ measured financial literacy using three questions, while Van Rooij et al. [8], used five questions; however, Stango and Zinman [19] used only one question to measure financial literacy. Although the number of questions used to measure financial literacy differs, recent studies $[15,16,20]$ mostly have followed the methodology of Lusardi and Mitchell $[15,16]$, and we did as well. The questions used to measure financial literacy were the following:

1. Suppose you had $¥ 10,000$ in a savings account, the interest rate is 2 percent per year, and you never withdraw money or interest payments. After 5 years, how much would you have in this account?

2. Assume that the interest rate on your savings account is 1 percent per year and inflation is 2 percent per year. After 1 year, how much would you be able to buy with the money in this account?

3. Please indicate whether the following statement is true or false: "Buying a company stock usually provides a safer return than does a stock mutual fund".

Based on these three questions, we developed a financial literacy index. We measured each correct answer by assigning one point for it and did not deduct any points for wrong answers.

To investigate how financial literacy relates to household decisions on investment in risky assets, we controlled several factors related to respondents' demographic, socioeconomic, and psychological backgrounds. Previous studies have found that people's investment behaviors and financial decisions are affected by demographic factors, such as their gender, age, education, marital status, and number of children [21-25]. The findings of these studies suggest that men, young investors, educated investors, unmarried investors, and investors without children are more likely to invest in risky assets. Thus, we controlled for respondents' gender, age, marital status, living with children, and education.

In addition, we controlled for employment status and the occupations of investors, because employed people have more chance of knowing about financial issues from the workplace and are expected to have an incentive to invest in risky assets. On the other hand, unemployed people who are already in a risky position might not find investment 
in risky assets worthwhile [26]. Similarly, people working in finance- and investmentrelated fields are more likely to invest in risky assets. In our study, we considered "financeand insurance-related jobs" as occupations that could positively influence investment in risky assets. Previous studies have provided evidence of a wealth effect on stock market participation; wealth affects stock market participation positively [22,24-27]. Campbell [22] argued that wealth is not the only household factor that predicts willingness to invest in stocks; income and other demographic features are also important. As a result, we controlled for people's wealth status and earning capacity to understand the effect of financial literacy on investment in risky assets.

We included four behavioral variables, such as peoples' orientation to the future versus the present, current state of financial satisfaction, anxiety about life in old age, and lack of trust to control people's behavioral and psychological features. Peoples' orientation to the future versus the present, also known as time preference, could affect investment in risky assets. People who place more emphasis on the present are more likely to have low incentive for investment in risky assets. Our second behavioral variable, the current state of financial satisfaction, could affect investment in risky assets, because individuals who are satisfied with current financial status might not be willing to make risky investments. The third behavioral variable, anxiety about life in old age, could affect investment in risky assets, since people who are anxious about financial security in old age might not consider risky investment a good option. Finally, we used lack of trust as our fourth behavioral variable, which could affect investment in risky assets. Khan et al. [9] and Guiso et al. [28] studied how a general lack of trust affects participation in the stock market. Generally, investors consider the risk of being cheated before deciding whether to buy stocks. Guiso et al. [28] documented that less trusting individuals buy less stocks, which is evident in the U.S., among other countries. Table 1 shows the definitions and measurements of variables.

Table 1. Variable definitions.

\begin{tabular}{cc}
\hline Variable & Definition \\
\hline Investment in risky assets & $\begin{array}{c}\text { Dependent variable } \\
\text { government in stocks, investment trusts, futures/options, foreign currency deposits, Japanese } \\
\text { measured both as a percentage of total assets and percentage of respondents holding those assets. }\end{array}$ \\
\hline
\end{tabular}

Independent variables

Financial literacy

$$
\begin{aligned}
& \text { Gender } \\
& \text { Age } \\
& \text { Spouse }
\end{aligned}
$$

Living with children Education

Household income

Household assets

Employment status Occupation

Future orientation

Anxiety

Financial satisfaction

Lack of trust

Financial literacy shows respondents' ability to understand basic financial calculations, inflation, and risks of financial securities. Financial literacy scores are calculated by the number of correct answers from three financial literacy questions. Financial literacy is a continuous variable ranging from 0 to 1 .

$1=$ male, $0=$ female

Age of respondents

$1=$ married, $0=$ otherwise

$1=$ respondents who are currently living with children, $0=$ otherwise Years of education

Household income of the respondents measured in million yen.

Balance of financial assets of the entire household measured in million yen.

$1=$ respondents who are currently employed, $0=$ otherwise

$1=$ respondents working in finance and insurance sectors, $0=$ all other occupations

Respondents' perceptions about the future, which was measured by the following statement:

"Since the future is uncertain, it is a waste of time thinking about it" ( 1 being completely disagree and 5 being completely agree).

Respondents' anxiety about life in old age, which was measured by the following statement:

"I have anxieties about my life after I turn 65" ( 5 being the highest and 1 being the lowest).

Respondents' current level of financial satisfaction, which was measured by the following statement: "How satisfied are you with the current financial situation of your family?"

( 5 being highest satisfaction and 1 being lowest satisfaction).

Respondents' trust of other people, which was measured by the following statement: "In general, most people are trustworthy" (1 being completely agree and 5 being completely disagree). 


\section{Data and Methods}

\subsection{Data}

We used micro data from the Preference Parameters Study of Osaka University's 21st Century Center of Excellence (COE) Program, "Behavioral Macrodynamics Based on Surveys and Experiments", and its Global COE project "Human Behavior and Socioeconomic Dynamics". The study used a multistage sampling and allocation method for the data. A nationwide survey was conducted in Japan with data collected between December 2011 and May 2012. The data collection methods included visits and placement surveys. Two-stage stratified random sampling was applied. First, the prefectures of Japan were divided into 10 regional blocks, namely, Hokkaido, Tohoku, Kanto, Koshinetsu, Hokuriku, Tokai, Kinki, Chugoku, Shikoku, and Kyushu. Then, each of the 10 regions was subdivided into four strata, namely, government-designated major cities, cities with populations of more than 100,000, cities with populations of less than 100,000, and towns and villages. The preference parameter study used face-to-face interviews and other approaches to receive responses from the subjects. The final sample size of our study was 3051.

Table 2 shows descriptive statistics of the key variables. The respondents' features were the following: $49.56 \%$ were female, the average age was 52.32 years $(\mathrm{SD}=12.62), 82.73 \%$ were married, and there was an average of $13.37(\mathrm{SD}=2.14)$ years of education. The statistics also show that $57.88 \%$ of respondents live with their children. Among other control variables, most respondents were found to be employed (mean $=70.60 \%$, SD $=45.57 \%$ ), but a low percentage worked in finance and investment area (mean $=2.52 \%, \mathrm{SD}=15.69 \%$ ). The average household assets and incomes of respondents were $¥ 14.11$ million (SD $=¥ 18.35$ million) and $¥ 6.38$ million ( $\mathrm{SD}=¥ 3.74$ million), respectively. Regarding behavioral issues, respondents were found to show a mediocre orientation to the future versus the present, slightly more than the average level of financial satisfaction, a higher degree of anxiety about life in old age, and an average level of lack of trust in others.

The results show that $37.59 \%$ of the respondents had invested in risky assets; however, investment in risky assets as a percentage of total assets was 9.88\% (SD $=19.24 \%$ ), which clearly shows the low level of participation in risky assets for Japanese households. Results further show that $30.94 \%(\mathrm{SD}=46.23 \%$ ) of the respondents had investment in equity securities, of which $25.92 \%(\mathrm{SD}=43.83 \%$ ) had investment in equity securities only. On the other hand, $11.87 \%(\mathrm{SD}=32.34 \%)$ of the respondents had investment in bonds and foreign currencies, of which $5.46 \%(\mathrm{SD}=22.72 \%)$ had investment in bonds and foreign currencies only. Our results show that Japanese people had lower investment, particularly in bonds and foreign currencies, compared to equity securities. Moreover, investment in equity securities and investment in bonds and foreign currencies have some interdependence. The results show that $26.17 \%(\mathrm{SD}=43.98 \%)$ of equity securities holders had investment in bonds and foreign currencies, while $68.23 \%$ of bond and foreign currency holders had investment in equity securities. Financial literacy, the independent variable, was found to be mediocre, that is, $0.61(\mathrm{SD}=0.33$ ) out of 1 , showing that respondents could understand basic financial calculations and implications of inflation but were unfamiliar with the risks of financial securities. Taken together, the results show that both financial literacy and investment in risky assets are low in Japan.

Table 3 shows investment in risky assets based on financial literacy and several important demographic features of respondents. As expected, respondents who scored higher in financial literacy had higher investment in risky assets. Male and married respondents were found to invest a little more in risky assets than female and unmarried respondents, respectively. We classified respondents into three age categories, i.e., <40 years, 41-65 years, and $>65$ years. Older respondents were found to invest more in risky assets than younger respondents. Finally, education classification showed that respondents with higher education tended to invest more in risky assets. The results showing higher investment in risky assets by financially literate, educated, and male respondents are similar to the findings for other countries. However, unmarried and younger respondents are usually found to invest more in risky assets, which our findings do not support. 
Table 2. Descriptive statistics.

\begin{tabular}{|c|c|c|c|c|c|}
\hline Variable & Obs. & Mean & Std. Dev. & Min & Max \\
\hline Investment in risky assets ( $\%$ of total assets) & 3051 & 0.0988 & 0.1924 & 0 & 1 \\
\hline Investment in risky assets ( $\%$ of total respondents) & 3051 & 0.3759 & 0.4844 & 0 & 1 \\
\hline Investment in equity securities (\% of total respondents) & 3051 & 0.3094 & 0.4623 & 0 & 1 \\
\hline Investment in equity securities only ( $\%$ of total respondents) & 3051 & 0.2592 & 0.4383 & 0 & 1 \\
\hline Investment in bonds and foreign currencies by equity securities holders & 944 & 0.2617 & 0.4398 & 0 & 1 \\
\hline Investment in bonds and foreign currencies (\% of total respondents) & 3051 & 0.1187 & 0.3234 & 0 & 1 \\
\hline Investment in bonds and foreign currencies only ( $\%$ of total respondents) & 3051 & 0.0546 & 0.2272 & 0 & 1 \\
\hline Investment in equity securities by bond and foreign currency holders & 362 & 0.6823 & 0.4662 & 0 & 1 \\
\hline Fliteracy & 3051 & 0.6161 & 0.3331 & 0 & 1 \\
\hline Age & 3051 & 52.3209 & 12.6177 & 22 & 78 \\
\hline Gender & 3051 & 0.4956 & 0.5001 & 0 & 1 \\
\hline Spouse & 3051 & 0.8273 & 0.3781 & 0 & 1 \\
\hline Childlt & 3051 & 0.5788 & 0.4938 & 0 & 1 \\
\hline Educ & 3051 & 13.3651 & 2.1350 & 9 & 21 \\
\hline Emplstatus & 3051 & 0.7060 & 0.4557 & 0 & 1 \\
\hline Occupation & 3051 & 0.0252 & 0.1569 & 0 & 1 \\
\hline Asset & 3051 & 14.1077 & 18.3505 & 1.25 & 100 \\
\hline Income & 3051 & 6.3782 & 3.7420 & 0.5 & 20 \\
\hline Future & 3051 & 2.7001 & 0.8502 & 1 & 5 \\
\hline Finsatisfaction & 3051 & 2.9803 & 1.0283 & 1 & 5 \\
\hline Anxiety & 3051 & 3.4218 & 1.0889 & 1 & 5 \\
\hline Lack of trust & 3051 & 2.8102 & 0.7094 & 1 & 5 \\
\hline
\end{tabular}

Table 3. Description of investment in risky assets by selected variables.

\begin{tabular}{cc}
\hline & Investment in Risky Assets \\
\hline Financial Literacy & $0.0564(0.1577)$ \\
\hline$<0.5$ & $0.1202(0.2045)$ \\
\hline Gender & \\
\hline Male & $0.1052(0.1942)$ \\
Female & $0.0924(0.1906)$ \\
\hline Marital status & \\
\hline Married & $0.1012(0.1918)$ \\
Unmarried & $0.0872(0.1953)$ \\
\hline Age & \\
\hline$<40$ & $0.0553(0.1500)$ \\
$41-65$ & $0.1001(0.1940)$ \\
$>65$ & $0.1441(0.2165)$ \\
\hline Education & \\
\hline$<12$ & $0.0547(0.1363)$ \\
$12-16$ & $0.1143(0.2013)$ \\
$>16$ & $0.1793(0.2362)$ \\
\hline
\end{tabular}

\subsection{Methods}

We used OLS (Model 1) and GSEM in Probit (Model 2) regression models to examine the association between financial literacy and investment in risky assets. In Model 1, investment in risky assets measured as respondents' holding of risky assets as a percentage of total assets is used as the dependent variable, while financial literacy is used as an independent variable. We also used several variables to control respondents' demographic, 
socio-economic, and psychological backgrounds. The OLS model used in this study is given as follows:

$$
\begin{aligned}
& \text { Investment in risky assets }{ }_{i} \\
& =\beta_{0}+\beta_{1} \text { financial literacy }_{i}+\beta_{2} \text { age }_{i}+\beta_{3} \text { gender }_{i} \\
& +\beta_{4} \text { marital status }_{i}+\beta_{5} \text { education }_{i} \\
& +\beta_{6} \text { living with children }{ }_{i}+\beta_{7} \text { household income }_{i} \\
& +\beta_{8} \text { household assets }_{i} \\
& +\beta_{9} \text { employment status } i+\beta_{10} \text { occupation }_{i} \\
& +\beta_{11} \text { future orientation }_{i}+\beta_{12} \text { financial satis faction }_{i} \\
& +\beta_{13} \text { anxiety }_{i}+\beta_{14}{\text { lack of } \text { trust }_{i}+\varepsilon_{i}}
\end{aligned}
$$

In Model 2, we used a binary variable for whether respondents had invested in risky assets as a dependent variable. The dummy variable takes the value of 1 if respondents have investments in stocks, investment trusts, futures/options, Japanese government bonds, government bonds of foreign countries, and foreign currency deposits, and 0 otherwise. We used financial literacy as the main independent variable and the same control variables as used in Model 1. We used the GSEM in probit model because of its capacity to control a probable endogeneity problem in the model specification. The GSEM handles endogeneity by including common, unobserved components into the equations for many variables. The GSEM in the probit model used in this study is given as follows:

$$
\begin{aligned}
& \text { Investment in risky assets }{ }_{i}(1=\text { investment in risky assets and } 0 \text { otherwise }) \\
& =\beta_{0}+\beta_{1} \text { financial literac }_{i}+\beta_{2} \text { age }_{i}+\beta_{3} \text { gender }_{i} \\
& +\beta_{4} \text { marital status }_{i}+\beta_{5} \text { education }_{i} \\
& +\beta_{6} \text { living with children }_{i}+\beta_{7} \text { household income }_{i} \\
& +\beta_{8} \text { household assets }_{i} \\
& +\beta_{9} \text { employment status } i+\beta_{10} \text { occupation }_{i} \\
& +\beta_{11} \text { future orientation }_{i}+\beta_{12} \text { financial satisfaction }_{i} \\
& +\beta_{13} \text { anxiety }_{i}+\beta_{14} \text { lack of trust }_{i}+\varepsilon_{i}
\end{aligned}
$$

\section{Results}

Table 4 shows the coefficients of the OLS and GSEM in probit regression models. The results for the OLS model (Model 1) show that financial literacy has a significantly positive association with investment in risky assets. The result indicates that financially literate people are more likely to invest in risky assets. Among the control variables, age, education, occupation in the finance and insurance area, and household assets have significantly positive association when employment status has a significantly negative association with the investment in risky assets; however, we found no significant associations for gender, marital status, living with children, household income, orientation to the future, current level of financial satisfaction, anxiety about life in old age, and lack of trust with investment in risky assets.

The results for the GSEM in the probit model (Model 2) also show that financial literacy has a significantly positive association with investment in risky assets, implying that financially literate people are more likely to invest in risky assets. Among the control variables, age, marital status, education, occupation in the finance and insurance area, household income, and household assets have significantly positive associations while living with children, and employment status have significantly negative associations with the investment in risky assets; however, we found no significant associations for gender, orientation to the future, current level of financial satisfaction, anxiety about life in old age, and lack of trust with the investment in risky assets. 
Table 4. Estimation results.

\begin{tabular}{ccc}
\hline Variables & Model 1 & Model 2 \\
\hline Fliteracy & $0.0606(5.65)^{* * * *}$ & $0.6669(8.22)^{* * *}$ \\
Age & $0.0017(5.26)^{* * *}$ & $0.0111(4.52)^{* * *}$ \\
Gender & $0.0032(0.46)$ & $0.0554(1.05)$ \\
Spouse & $0.0015(0.14)$ & $0.1301(1.70)^{*}$ \\
Childlt & $-0.0023(-0.29)$ & $-0.1151(2.00)^{* *}$ \\
Educ & $0.0102(5.94)^{* * *}$ & $0.0817(6.39)^{* * *}$ \\
Emplstatus & $-0.0284(-3.49)^{* * *}$ & $-0.1847(-3.07)^{* * *}$ \\
Occupation & $0.0970(4.56)^{* * *}$ & $0.4585(2.96)^{* * *}$ \\
Assets & $0.0017(8.37)^{* * *}$ & $0.0181(11.02)^{* * *}$ \\
Income & $0.0004(0.39)$ & $0.0258(3.43)^{* * *}$ \\
Future & $0.0002(0.04)$ & $-0.0008(-0.03)$ \\
Finsatisfaction & $0.0019(0.51)$ & $0.0466(1.64)^{*}$ \\
Anxiety & $-0.0023(-0.67)$ & $-0.0183(-0.71)$ \\
Lack of trust & $0.0008(0.18)$ & $-0.0159(-0.44)$ \\
cons & $-0.1759(-4.12)^{* * *}$ & $-2.8362(-8.82)^{* * *}$ \\
\hline Obs. & 3051 & 3051 \\
Log likelihood & & -1722.2288 \\
F & $26.42^{* * *}$ & \\
Adj. $\mathrm{R}^{2}$ & 0.1045 & \\
\hline
\end{tabular}

Note: Z-values in parentheses. ${ }^{* * *} p<0.01,{ }^{* *} p<0.05,{ }^{*} p<0.1$.

As investment in risky assets includes both investment in equity securities and investment in bonds and foreign currencies, we separately examined the association of financial literacy with investment in equity securities and investment in bonds and foreign currencies. As in the original model, we applied the same GSEM in the probit regression model and used the same independent and control variables. For estimating the association between financial literacy and investment in equity securities, we used the binary response of whether respondents have investments in stocks, investment trusts, and futures/options as the dependent variable. On the other hand, for estimating the association between financial literacy and investment in bonds and foreign currencies, the binary response of whether respondents have investments in Japanese government bonds, government bonds of foreign countries, and foreign currency deposits was used as the dependent variable. The regression equations were the following:

$$
\begin{aligned}
& \text { Investment in equity securitiess } s_{i}(1 \\
& =\text { investment in equity securities, and } 0 \text { otherwise) } \\
& =\beta_{0}+\beta_{1} \text { financial literacy }_{i}+\beta_{2} \text { age }_{i}+\beta_{3} \text { gender }_{i} \\
& +\beta_{4} \text { marital status }_{i}+\beta_{5} \text { education }_{i} \\
& +\beta_{6} \text { living with children }{ }_{i}+\beta_{7} \text { household income }_{i} \\
& +\beta_{8} \text { household assets }_{i} \\
& +\beta_{9} \text { employment status }{ }_{i}+\beta_{10} \text { occupation }_{i} \\
& +\beta_{11} \text { future orientation }{ }_{i}+\beta_{12} \text { financial satis faction }_{i} \\
& +\beta_{13} \text { anxiety }_{i}+\beta_{14} \text { lack of trust }_{i}+\varepsilon_{i}
\end{aligned}
$$

Investment in bonds and foreign currencies ${ }_{i}(1$

$=$ investment in bonds and foreign currencies, and 0 otherwise)

$=\beta_{0}+\beta_{1}$ financial literacy $_{i}+\beta_{2}$ age $_{i}+\beta_{3}$ gender $_{i}+\beta_{4}$ marital status $_{i}$

$+\beta_{5}$ education $_{i}+\beta_{6}$ living with children ${ }_{i}+\beta_{7}$ household income $_{i}$

$+\beta_{8}$ household assets $_{i}+\beta_{9}$ employment status ${ }_{i}+\beta_{10}$ occupation $_{i}$

$+\beta_{11}$ future orientation $_{i}+\beta_{12}$ financial satisfaction $_{i}+\beta_{13}$ anxiety $_{i}$

$+\beta_{14}$ lack of trust $_{i}+\varepsilon_{i}$

Table 5 shows the GSEM in the probit regression coefficients to estimate the association of financial literacy with investment in equity securities (Model 3) and investment in 
bonds and foreign currencies (Model 4). The results of Model 3 show that financial literacy has a significantly positive association with the investment in equity securities, implying that financially literate people are more likely to invest in equity securities. Among the control variables, we found that age, gender, marital status, education, occupation in the finance and insurance area, household assets, and household income have significantly positive associations when employment status has a significantly negative association with investment in equity securities; however, we found no association of living with children, orientation to the future, current level of financial satisfaction, anxiety about life in old age, and lack of trust with investment in equity securities. The results of Model 4 show a significantly positive association between financial literacy and investment in bonds and foreign currencies, implying that financially literate people are more likely to invest in bonds and foreign currencies. Among the control variables, age, education, occupation in the finance and insurance area, household assets, and current level of financial satisfaction have significantly positive associations, while gender has a significantly negative association with investment in bonds and foreign currencies; however, we found no associations for marital status, living with children, employment status, household income, orientation to the future, anxiety about life in old age, and lack of trust with investment in bonds and foreign currencies.

Table 5. Estimation results for investment in equity securities and investment in bonds and foreign currencies.

\begin{tabular}{ccc}
\hline & $\begin{array}{c}\text { Investment in } \\
\text { Equity Securities }\end{array}$ & $\begin{array}{c}\text { Investment in Bonds and } \\
\text { Foreign Currencies }\end{array}$ \\
\hline Fliteracy & $0.7511(8.77)^{* * *}$ & $0.6747(6.01)^{* * *}$ \\
Age & $0.0128(4.94)^{* * *}$ & $0.0063(1.94)^{*}$ \\
Gender & $0.0900(1.65)^{*}$ & $-0.1743(-2.55)^{* *}$ \\
Spouse & $0.2147(2.67)^{* * *}$ & $-0.0618(-0.65)$ \\
Childlt & $-0.0954(-1.61)$ & $0.0287(0.39)$ \\
Educ & $0.0739(5.61)^{* * *}$ & $0.0497(3.02)^{* * *}$ \\
Emplstatus & $-0.2278(-3.65)^{* * *}$ & $-0.0961(-1.25)$ \\
Occupation & $0.5270(3.41)^{* * *}$ & $0.4092(2.39)^{* *}$ \\
Assets & $0.0171(10.71)^{* * *}$ & $0.0170(10.50))^{* * *}$ \\
Income & $0.0186(2.44)^{* *}$ & $-0.0087(-0.93)$ \\
Future & $-0.0051(-0.17)$ & $0.0288(0.76)$ \\
Finsatisfaction & $0.0485(1.64)$ & $0.1080(2.87))^{* * *}$ \\
Anxiety & $-0.0302(-1.13)$ & $0.0192(0.58)$ \\
lack of trust & $-0.0257(-0.69)$ & $-0.0148(-0.31)$ \\
cons & $-3.0317(-9.01)^{* * *}$ & $-3.1714(-7.43) * * *$
\end{tabular}

\section{Discussion}

Despite the opportunity to achieve higher returns, why people do not invest in risky assets in financial markets remains a puzzle in empirical finance. Recent studies have partially explained the phenomenon by associating financial literacy with the lack of investment in stocks [8-11]; however, it is still inconclusive whether the explanation is valid for risky securities other than stocks. Moreover, investigating the validity of the previous explanation in a culturally different country like Japan is also important. Japan is a homogenous and collectivist society where people place higher importance on savings than investment in risky securities. Although, Yamori and Ueyama [12] and Kawamura et al. [13] investigated financial literacy's role in explaining stock investment in Japan, the results are not consistent. While Yamori and Ueyama [12] provided evidence that financial literate people are more likely to invest in stock, Kawamura et al. [13] found that financially literate people were not so prudent in investing in financial securities. With this background, we investigated how financial literacy is associated with investment in risky assets in Japan. 
We have provided evidence that financially literate people are more likely to invest in risky assets in the financial markets. To provide detailed evidence on the role of financial literacy in investing in risky assets, we performed separate regression analyses for investment in equity securities and investment in bonds and foreign currencies. Our results imply that financially literate people are not only likely to invest in stocks but are also likely to invest in other risky securities, such as bonds and foreign currencies. Our study provides novel evidence regarding the role of financial literacy in investing in bonds and foreign currencies in addition to investing in equity securities, as already evident in Japan [12] and other countries $[8,10,11]$. We argue that financial literacy makes people aware and knowledgeable about the risk and return phenomena of investment in financial markets and motivates them to invest in risky securities. Financial literacy also helps to reduce the cost of trading of securities through the selection of appropriate trading strategies. Furthermore, financially literate people have a greater cognitive ability, which is a positive contributor to investing in risky assets [29]. Our explanation is also consistent with the studies attributing participation in the financial markets to awareness and proper knowledge of investment [22,30-33].

Our study also provides evidence that education and experience in working in the finance and insurance area are positively associated with investment in risky assets. Since education and working experience in the financial sector make people knowledgeable and aware about investment opportunities, it is likely that these people will invest in risky assets. Our study further shows that respondents who have more household assets and income are likely to have investment in risky assets. Our results are consistent with previous findings that wealth has a positive influence on investment in financial securities [22,23,26]; however, our findings on gender, age, marital status, and employment status are not consistent with previous studies [22,25,34-37].

\section{Conclusions}

This study examines whether financial literacy explains the lack of investment in risky assets in Japan. Using data from Osaka University's Preference Parameter study, we have provided evidence that financial literacy has a significantly positive association with the investment in risky assets. We argue that financial literacy increases investment in risky assets through enhanced awareness, reduction of the cost of participation, and increased cognitive ability. In examining the role of financial literacy in investing in risky assets, we controlled for several demographic, socio-economic, and psychological factors. We checked the robustness of our results by separately examining the role of financial literacy in investing in equity securities and bonds and foreign currencies. Financial literacy was found to be associated with both investment in equity securities and investment in bonds and foreign currencies. Our results suggest that the lack of financial literacy contributes to the lack of investment in risky assets in Japan.

Our study has some limitations which readers should consider while interpreting the results. First, we mainly used data from the 2012 wave of the PPS, but we used financial literacy and education data from the 2010 and 2011 waves, respectively. Although the respondents were identical in all waves, we cannot ignore a possible effect of this time difference on the results of the study; however, we believe that the results and implications of our study would not be materially affected as the demographic, socioeconomic, and psychological backgrounds do not usually change much in the adjacent years. Second, the measurement of psychological variables might not be accurate because some respondents could make extreme choices, whereas others could make moderate choices. Future research should avoid these limitations to provide more accurate findings regarding the association between financial literacy and investment in risky assets. Moreover, a cross-country investigation could be initiated to more clearly understand the role of financial literacy in explaining the conservative investment behavior of Japanese people.

Nevertheless, our study has important economic and policy implications for all countries. From an economic viewpoint, a lack of financial literacy acts as a barrier to wealth- 
maximizing investment, which ultimately hurts national economic success; however, our study also suggests that financial literacy is not an automatic outcome of development. Proper financial education, financial orientation in the workplace, and social interaction can improve financial literacy, which, in turn, can improve investment in risky assets.

Author Contributions: Conceptualization, M.S.R.K. and Y.K.; methodology, M.S.R.K., Y.K. and N.R.; software, M.S.R.K. and Y.K.; validation, M.S.R.K., N.R. and Y.K.; formal analysis, M.S.R.K., N.R. and Y.K.; investigation, M.S.R.K., N.R. and Y.K.; resources, Y.K. and M.S.R.K.; data curation, M.S.R.K., N.R. and Y.K.; writing—original draft preparation, M.S.R.K., N.R. and Y.K.; writing—review and editing, M.S.R.K., N.R. and Y.K.; visualization, M.S.R.K., N.R. and Y.K.; supervision, Y.K. and M.S.R.K.; project administration, Y.K.; funding acquisition, Y.K. and M.S.R.K. All authors have read and agreed to the published version of the manuscript.

Funding: This work is financially supported by the JSPS KAKENHI (grant number 19K13739) and (grant number 19K13684), The Chugoku Regional Economic Research Association Grant, and RISTEX, JST.

Institutional Review Board Statement: Not applicable.

Informed Consent Statement: Not applicable.

Data Availability Statement: Data is available on request.

Acknowledgments: This research used micro data from the Preference Parameters Study of Osaka University's 21st Century COE Program, "Behavioral Macrodynamics Based on Surveys and Experiments" and its Global COE project, "Human Behavior and Socioeconomic Dynamics". The authors acknowledge the program/project's contributors: Yoshiro Tsutsui, Fumio Ohtake, and Shinsuke Ikeda. We are also grateful for helpful comments from Somtip Watanapongvanich, and Pongpat Putthinun.

Conflicts of Interest: The authors declare no conflict of interest. The funders had no role in the study design, data collection and analysis, preparation of the manuscript, or decision to publish.

\section{References}

1. Gomes, F.; Michaelides, A. Optimal life-cycle asset allocation: Understanding the empirical evidence. J. Financ. 2005, 60, 869-904. [CrossRef]

2. Bucks, B.K.; Kennickell, A.B.; Mach, T.L.; Moore, K.B. Recent changes in U.S. family finances from 2004 to 2007: Evidence from the Survey of Consumer Finances. Fed. Reserve Bull. 2009, 95, A1-A56.

3. Fagereng, A.; Gottlieb, C.; Guiso, L. Asset market participation and portfolio choice over the life-cycle. J. Financ. 2017, 72, 705-750. [CrossRef]

4. Iwamoto, M.; Kawano, S.; Clenfield, J. Japan's Fear of Risk Is Getting Dangerous. Bloomberg. 6 December 2012. Available online: https:/ / www.bloomberg.com/news/articles/2012-12-06/japans-fear-of-risk-is-getting-dangerous\#p2 (accessed on 5 April 2021).

5. Giannetti, M.; Koskinen, Y. Investor protection, equity returns, and financial globalization. J. Financ. Quant. Anal. 2010, 45, 135-168. [CrossRef]

6. Seigel, J.J. Stocks for the Long Run; McGraw-Hill: New York, NY, USA, 2014.

7. Rayan, C. In a Bond Market Gone Bonkers, Japan is the New 'High Yielder'. Bloomberg. 15 August 2019. Available online: https: / /www.bloomberg.com/news/articles/2019-08-15/in-a-bond-market-gone-bonkers-japan-is-the-new-high-yielder (accessed on 17 April 2021).

8. Van Rooij, M.; Lusardi, A.; Alessie, R. Financial literacy and stock market participation. J. Financ. Econ. 2011, 101, 449-472. [CrossRef]

9. Khan, M.S.R.; Rabbani, N.; Kadoya, Y. Is Financial Literacy Associated with Investment in Financial Markets in the United States? Sustainability 2020, 12, 7370. [CrossRef]

10. Yoong, J. Financial illiteracy and stock market participation: Evidence from the Rand American Life Panel. In Financial Literacy: Implications for Retirement Security and the Financial Marketplace; Mitchell, O.S., Lusardi, A., Eds.; Oxford University Press: Oxford, UK, 2011; pp. 76-97.

11. Thomas, A.; Spataro, L. Financial literacy, human capital and stock market participation in Europe. J. Fam. Econ. Issues 2018, 39, 532-550. [CrossRef]

12. Yamori, N.; Ueyama, H. Financial literacy and low stock market participation of Japanese household. Financ. Res. Lett. 2021, 102074. [CrossRef] 
13. Kawamura, T.; Mori, T.; Motonishi, T.; Ogawa, K. Is financial literacy dangerous? Financial literacy, behavioral factors, and financial choices of households. J. Jpn. Int. Econ. 2021, 60, 101131. [CrossRef]

14. Sekita, S. Financial Literacy and Wealth Accumulation: Evidence from Japan; Discussion Paper No. 2013-01; Graduate School of Economics, Kyoto Sangyo University: Kyoto, Japan, 2013.

15. Kadoya, Y.; Khan, M.S.R. Can financial literacy reduce anxiety about life at the old age? J. Risk Res. 2018, 21, 1533-1550. [CrossRef]

16. Kadoya, Y.; Khan, M.S.R. What determines financial literacy in Japan? J. Pension Econ. Financ. 2020, 19, 353-371. [CrossRef]

17. Lusardi, A.; Mitchell, O.S. Financial literacy and retirement preparedness: Evidence and implications for financial education. Bus. Econ. 2007, 42, 35-44. [CrossRef]

18. Lusardi, A.; Mitchell, O.S. Planning and financial literacy: How do women fare? Am. Econ. Rev. 2008, 98, 413-417. [CrossRef]

19. Stango, V.; Zinman, J. Exponential growth bias and household finance. J. Financ. 2009, 64, 2807-2849. [CrossRef]

20. Kadoya, Y.; Khan, M.S.R. Financial literacy in Japan: New evidence using financial knowledge, behavior and attitude. Sustainability 2020, 12, 3683. [CrossRef]

21. Haliassos, M.; Bertaut, C.C. Why do so few hold stocks? Econ. J. 1995, 105, 1110-1129. [CrossRef]

22. Campbell, J.Y. Household finance. J. Financ. 2006, 61, 1553-1604. [CrossRef]

23. Mankiw, N.G.; Zeldes, S.P. The consumption of stockholders and non-stockholders. J. Financ. Econ. 1991, 29, 97-112. [CrossRef]

24. Yoo, P.S. Age Dependent Portfolio Selection; Working Paper; Federal Reserve Bank of Saint Louis: Saint Louis, MO, USA, 1994.

25. Guiso, L.; Haliassos, M.; Jappelli, T. Stockholding: A European comparison. In Stockholding in Europe; Guiso, L., Haliassos, M., Jappelli, T., Eds.; Palgrave Macmillan: Basingstoke, UK, 2002; pp. 3-29.

26. Heaton, J.; Lucas, D. Portfolio choice and asset prices: The importance of entrepreneurial risk. J. Financ. 2000, 55, 1163-1198. [CrossRef]

27. Poterba, J.M.; Samwick, A.A.; Shleifer, A.; Shiller, R.J. Stock ownership patterns, stock market fluctuations, and consumption. Brook. Pap. Econ. Act. 1995, 1995, 295-372. [CrossRef]

28. Guiso, L.; Sapienza, P.; Zingales, L. Trusting the stock market. J. Financ. 2008, 63, 2557-2600. [CrossRef]

29. Christelis, D.; Jappelli, T.; Padula, M. Cognitive abilities and portfolio choice. Eur. Econ. Rev. 2010, 54, 18-38. [CrossRef]

30. Hong, H.; Kubik, J.D.; Stein, J.C. Social interaction and stock market participation. J. Financ. 2004, 59, 137-163. [CrossRef]

31. Guiso, L.; Jappelli, T. Awareness and stock market participation. Rev. Financ. 2005, 9, 537-567. [CrossRef]

32. Calvet, L.E.; Campbell, J.Y.; Sodini, P. Down or out: Assessing the welfare costs of household investment mistakes. J. Polit. Econ. 2007, 115, 707-747. [CrossRef]

33. Brown, J.R.; Ivković, Z.; Smith, P.A.; Weisbenner, S. Neighbors matter: Causal community effects and stock market participation. J. Financ. 2008, 63, 1509-1531. [CrossRef]

34. Jianakoplos, N.A.; Bernasek, A. Are women more risk averse? Econ. Inq. 1998, 36, 620-630. [CrossRef]

35. Almenberg, J.; Dreber, A. Gender, stock market participation and financial literacy. Econ. Lett. 2015, 137, 140-142. [CrossRef]

36. Ameriks, J.; Zeldes, S.P. How Do Household Portfolio Shares Vary with Age? Working Paper; Columbia University: New York, NY, USA, 2004.

37. Bertaut, C. Stockholding Behavior of U.S. Households: Evidence from the 1983-1989 Survey of Consumer Finances. Rev. Econ. Stat. 1998, 80, 263-275. [CrossRef] 